\title{
Preparasi dan Karakterisasi Kitosan-Karboksi Metil Selulosa Iradiasi untuk Scaffold
}

\section{Preparation and Characterization of Irradiated Chitosan-Carboxy Methyl Cellulose for Scaffold}

\author{
Basril Abbas dan Yessy Warastuti \\ Pusat Aplikasi Isotop dan Radiasi, BATAN \\ Jalan Lebak Bulus Raya No. 49, Jakarta Selatan 12440 \\ E-mail : baskara@batan.go.id
}

\begin{abstract}
ABSTRAK
Scaffold umumnya digunakan sebagai matrik pelepasan obat, penelitian perilaku sel dan material dalam bidang rekayasa jaringan. Scaffold berdimensi tiga (3D) biasanya berupa material berpori, biokompatibel, biodegradable dan berfungsi untuk memberikan lingkungan mikro yang cocok, yaitu dukungan mekanik, fisik, dan rangsangan biokimia untuk pertumbuhan sel optimal. Pada penelitian ini scaffold dibuat dari kitosan dan karboksimetil selulosa (KMS) dengan teknik liofilisasi. Selanjutnya, scaffold diiradiasi dengan sinar gamma dan dikarakterisasi dengan Fourier-Transform- Infrared, Scanning Electron Microscope (SEM), serapan air dan porositas. Hasil yang diperoleh menunjukkan bahwa pada spektrum FTIR diperoleh kedua bahan tersebut tanpa terjadi reaksi, ukuran pori berkisar 130-467 $\mu \mathrm{m}$, serapan air $803-1722 \%$, dan porositas berkisar $70-74 \%$. Iradiasi mempengaruhi ukuran pori, porositas, dan serapan air. Berdasarkan besaran porinya, komposit ini layak menjadi scaffold.
\end{abstract}

Kata Kunci : komposit, scaffold, kitosan, karboksi meteil selulosa, karakterisasi.

\begin{abstract}
Scaffolds are generally used for drug delivery, investigation of cell behavior and material studies in the field of tissue engineering. Three dimensional (3D) scaffolds are typically porous, biocompatible and biodegradable materials that serve to provide suitable microenvironments, that is, mechanical support, physical, and biochemical stimuli for optimal cell growth and function. In this study, the scaffold was prepared from chitosan and carboxy methyl cellulose (CMC) with lyophilization techniques. Furthermore, the scaffold was irradiated with gamma rays and characterized by using Fourier-Transform- Infrared (FTIR) and Scanning Electron Microscope (SEM). It is also detemined water absorption and porosity. The results showed that base on the FTIR spectrum both materials were obtained without reaction, pore size around $130-467$, water absorption $803-1722 \%$ and porosity around $70-74 \%$. Based on these results, this composite deserves to be a scaffold.
\end{abstract}

Key Words : composite, scaffold, chitosan, carboxy methyl cellulose, characterization

\section{PENDAHULUAN}

Polimer seperti protein, karbohidrat, dan lemak telah memainkan peranan yang besar dalam kehidupan manusia. Salah satu dari polimer alam yang banyak dimodifikasi dalam bidang polimer adalah polisakarida. Pencampuran dua atau lebih polimer untuk memperoleh bahan dengan sifat yang baru dan unik telah menjadi penting pula dalam topik penelitian di bidang biomaterial. Tujuan utama dari pencampuran polimer tersebut adalah untuk mendapatkan bahan dengan sifat yang lebih baik dari sifat masing-masing komponen penyusun campuran tersebut
Keberhasilan dari bahan polimer untuk biomaterial ditujukan untuk perbaikan sifat mekanik yang dihasilkan. Pencampuran bahan polimer tersebut banyak dilakukan dengan metode blending karena prosesnya lebih cepat dan lebih ekonomis dalam membuat bahan material baru [1].

Scaffold atau perancah adalah material penyangga baik dari bahan alam atau buatan yang dapat mempertahankan konfigurasi permukaan jaringan. Untuk fungsi yang efisien, scaffold harus memenuhi persyaratan tertentu. Diantara persyaratan itu adalah arsitektur yang tepat dan geometri dari scaffold yang diperlukan untuk 
penggantian jaringan atau organ. Disamping itu, ukuran pori-pori yang memadai dan porositas yang tinggi akan memungkinkan pemerataan pertumbuhan sel melalui struktur 3D, difusi nutrisi yang cukup untuk sel dan produk transportasi metabolit. Struktur rangka tiga dimensi seperti halnya pada scaffold efektif pada penelitian rekayasa jaringan $[2,3]$.

Pencampuran bahan polimer dapat meningkatkan sifat mekanik dan termal dari material yang dihasilkan. Dalam penelitian ini digunakan dua macam material yaitu kitosan dan KMS yang dicampur dengan metode blending dan diliofilisasi untuk mendapatkan scaffold yang ideal. Kitosan merupakan bio-polimer yang mengandung kation dan memiliki sifat yang unik. Sifat kitosan yang paling penting untuk aplikasi scaffold adalah, bahwa kitosan tidak toksik, biodegradable dan biokompatibel [4]. KMS adalah polisakarida yang penting untuk modifikasi berbagai bio-polimer. Polimer alam ini banyak dipelajari karena mudah diolah untuk dijadikan suatu produk. Salah satu jenis KMS yang penting dan banyak digunakan adalah Natrium Karboksimetil Selulosa (Na-KMS), seperti untuk industri (detergen dan lem wall paper). Na-KMS dengan kemurnian tinggi digunakan dalam obatobatan, pasta gigi dan makanan [5].

Kitosan dan KMS keduanya merupakan golongan polisakarida, sehingga struktur dari kedua bio-polimer ini sangat mirip. Perbedaan kitosan dan KMS terletak pada gugus amino pada kitosan diganti dengan gugus hidroksil pada KMS.

Tujuan penelitian ini adalah untuk memperoleh scaffold iradiasi dengan karakteristik sifat fisiko kimianya seperti Fourier-TransformInfrared (FTIR), pori, porositas, dan serapan air. Sebagai biomaterial, scaffold banyak digunakan dalam bidang kesehatan sebagai bahan implan. Salah satu persayaratan bahan implan adalah harus bebas dari kontaminasi mikroba. Untuk sterilisasi produk alat kesehatan radiasi merupakan pilihan yang banyak digunakan. Teknik sterilisasi radiasi mempunyai keunggulan dibandingkan dengan metode sterilisasi lain, diantaranya: kenaikan suhu selama proses sterilisasi tidak signifikan sehingga tidak terjadi perubahan fisika dan kimia yang berarti; radiasi dapat dilakukan pada produk yang telah dikemas dalam kontainer/ box karena penetrasi sinar gamma yang tinggi; tidak meninggalkan residu seperti sterilisasi dengan etilen oksida; dan proses kontrol yang sederhana [6].

\section{BAHAN DAN METODE}

\section{Bahan}

Kitosan diperoleh dari PT Biotek Surindo dengan spesifikasi medical grade. Kitosan berasal dari cangkang kepiting berbentuk bubuk putih 200 Mesh dengan derajat deasetilasi 94.5\%, viskositas 34,4 cps, kandungan air 8.68\%, dan kadar abu $0.85 \%$.

Karboksi Metil Selulosa diperoleh dari DaiChi Kogya Seiyaku Co. Ltd, kadar air 6.5\%, viskositas (1\% dalam Air) 365, pH (1\% dalam air) 6.7

\section{Metode}

Scaffold kitosan-KMS dibuat dengan metode blending dan liofilisasi. Sebanyak 2\% kitosan dan KMS masing-masing ditimbang dan dicampur dengan air. Campuran tersebut diaduk menggunakan magnetic stirer selama 1 jam. Ke dalam campuran tersebut ditambahkan 0,5 gram natrium bikarbonat dan pengadukan dilanjutkan 1 jam lagi, sehingga campuran tersebut bercampur dengan sempurna. Campuran tersebut dimasukkan ke dalam cetakan yang telah diisi dengan larutan asam asetat. Scaffold yang terbentuk dibekukan dalam deep freezer suhu $-80{ }^{\circ} \mathrm{C}$ selama 3 jam. Scaffold beku direndam dalam larutan natrium hidroksida $1 \mathrm{M}$ selama 2 jam, selanjutnya $\mathrm{pH}$ dinetralkan dengan mencuci scaffold dalam air. Pengeringan dilakukan dalam liofilizer hingga kadar air $<7 \%$. Sampel diiradisi dengan sinar gamma pada dosis 15 dan $25 \mathrm{kGy}$.

\section{Karakterisasi}

Pengukuran gugus fungsi dilakukan dengan Fourier-Transform- Infrared (FTIR) Shimadzu IR Prestige 21. Sejumlah sampel sampel dimasukkan ke dalam tempat sampel (pan) yang telah berisi kalium bromida (KBr). Sampel diukur pada daerah bilangan gelombang sedang 4000-400 $\mathrm{cm}^{-1}$ dengan resolusi $4 \mathrm{~cm}^{-1}$.

Sampel scaffold KS-KMS disiapkan dengan teknik pembekuan fraktur dimana sampel dibekukan kemudian dipatahkan. Struktur morfologi permukaan dari potongan tersebut dilapisi dengan carbon dan dikarakterisasi dengan Scanning Electron Microscope (SEM) Zeiss, EVO MA 10.

Serapan air scaffold KS-KMS dilakukan dengan metode perendaman sampel di dalam air pada suhu ruang. Sampel yang digunakan berbentuk kubus dengan volume $2 \mathrm{~cm}^{3}$. Sebelum 
direndam, sampel awal ditimbang sebagai $\mathrm{W}_{0}$. Perendaman dilakukan selama 30 menit dengan interval 5 menit kemudian sampel ditimbang kembali sebagai $\mathrm{W}_{1}$. Serapan air dihitung berdasarkan rumus:

$$
\text { Serapan air }=\frac{W 1-W 0}{W^{0}} \times 100 \%
$$

\section{Keterangan:}

$\mathrm{W}_{0}=$ berat kering sampel scaffold

$\mathrm{W}_{1}=$ berat sampel scaffold setelah perendaman dalam air.

Porositas didefinisikan sebagai rasio volume ruang kosong dengan volume massa dari material solid. Porositas scaffold KS-KMS ditentukan dengan merendam sampel dalam etanol absolut. Scaffold berukuran $2 \mathrm{~cm}^{3}$ ditimbang sebagai $\mathrm{W}_{0}$. Selanjutnya scaffold direndam dengan etanol absolut selama 30 menit, ditimbang sebagai $\left(\mathrm{W}_{1}\right)$. Persen porositas dihitung dengan rumus [3]:

$$
\text { Porositas }(\%)=\frac{W \perp-W 0}{W \times V} \times 100 \%
$$

Keterangan :

$\mathrm{W}_{1}=$ berat sampel scaffold setelah di rendam etanol absolut

$\mathrm{W}_{0}=$ berat sampel scaffold sebelum direndam etanol absolut

$\rho($ etanol absolut $)=0,790 \mathrm{~g} / \mathrm{cm} 3$

$\mathrm{V}_{0}$ scaffold $=2 \mathrm{~cm}^{3}$

\section{HASIL DAN PEMBAHASAN}

Spektrum FTIR dari kitosan (KS), KMS dan scaffold komposit KS-KMS ditampilkan pada Gambar 1. Karakteristika dari kitosan (Gambar 1B) ditunjukkan dengan adanya bilangan gelombang pada $3450 \mathrm{~cm}^{-1}$ yang berkaitan dengan peregangan getaran $-\mathrm{NH}_{2}$ dan $\mathrm{OH}^{-}$dan bilangan gelombang $1651 \mathrm{~cm}^{-1}$ yang merupakan karakteristik dari kelompok amida [7]. Pada spektrum tersebut juga muncul $\mathrm{C}-\mathrm{H}$ alifatik dengan bilangan gelombang $2879 \mathrm{~cm}^{-1}$ dan peregangan $\mathrm{N}-\mathrm{H}$ pada $1589 \mathrm{~cm}^{-1}$ (amida II). Di samping itu, terdapat pula $\mathrm{C}-\mathrm{H}$ asimetri dan $\mathrm{CH}_{2}$ tekuk pada bilangan gelombang $1410 \mathrm{~cm}^{-1}$ dan $1310 \mathrm{~cm}^{-1}$ (amida III) [4].
Spektrum FTIR dari KMS (Gambar 1A) menunjukkan adanya ion karboksilat $\left(-\mathrm{COO}^{-}\right)$ yang muncul pada bilangan gelombang $1587 \mathrm{~cm}^{-1}$, peregangan $\mathrm{C}-\mathrm{O}$ simetri pada bilangan gelombang $1111 \mathrm{~cm}^{-1}$ dan C-O-C pada bilangan gelombang $1630 \mathrm{~cm}^{-1}$ (Hsiao, et.al, 2012). Disamping itu, juga terdapat $\mathrm{N}-\mathrm{H}$ pada bilangan gelombang 3375 $\mathrm{cm}^{-1}$ dan $\mathrm{C}=\mathrm{C}$ pada bilangan gelombang $1587 \mathrm{~cm}^{-}$ ${ }^{1}$. Bilangan gelombang 1423 dan $1325 \mathrm{~cm}^{-1}$ pada KMS masing-masing merupakan gugus $\mathrm{C}-\mathrm{H}$ dan gugus hidroksil $(\mathrm{O}-\mathrm{H})$ tekuk [8].

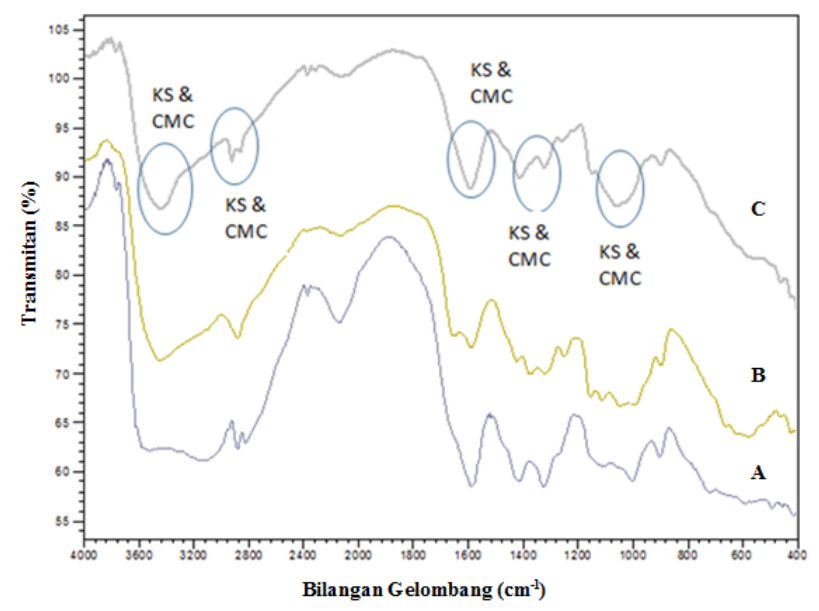

Gambar 1. Spektrum CMC (KMS) (A), Kitosan (B), dan komposit CMC (KMS)-KS (C).

Scaffold komposit kitosan dan KMS (Gambar 1C) memperlihatkan adanya serapan yang muncul pada bilangan gelombang $3429 \mathrm{~cm}^{-1}$ yaitu peregangan N-H (amida II dan amina primer) dan peregangan $\mathrm{OH}^{-}$. Selanjutnya, terdapat serapan pada bilangan gelombang 2924 $\mathrm{cm}^{-1}$ yang merupakan peregangan $\mathrm{C}-\mathrm{H}$ dari kelompok metil $\left(\mathrm{H}_{3} \mathrm{C}-\right)_{\text {berdimensi tiga dan pita }}$ bilangan gelombang $1092 \mathrm{~cm}^{-1}$ serta $1265 \mathrm{~cm}^{-1}$ yang merupakan $\mathrm{C}-\mathrm{O}-\mathrm{C}$ sebagai cincin polisakarida. Selanjutnya, pada scaffold ini juga muncul pita pada bilangan gelombang $1597 \mathrm{~cm}^{-1}$ $(\mathrm{N}-\mathrm{H})$ dan $1740 \mathrm{~cm}^{-1}(\mathrm{C}=\mathrm{O})$ yang memveri-fikasi bahwa komposit KS-KMS terdiri atas KS dan KMS.

Salah satu ciri dari scaffold adalah bahwa produk tersebut berupa material tiga dimensi yang berpori. Dari hasil pengamatan morfologinya dengan SEM (Gambar 2), scaffold KS-KMS menunjukkan scaffold berpori yang berbentuk poligonal dan memiliki struktur seperti lembaran kecil tiga dimensi. Pori yang berbentuk poligonal dan adanya struktur lembaran kecil tersebut dapat 
mempertahankan air lebih banyak dibandingkan dengan bentuk pori yang memanjang [9]. Diameter pori makro dari scaffold non-iradiasi dan iradiasi (dosis 15 dan $25 \mathrm{kGy}$ ) masing-masing adalah 265-467 $\mu \mathrm{m}, 130-400 \mu \mathrm{m}$ dan 159-355 $\mu \mathrm{m}$. Di samping pori-pori makro, terdapat poripori mikro $(<100 \mu \mathrm{m})$ di dalam maupun pada permukaan scaffold. Iradiasi memberikan pengaruh terhadap besaran pori scaffold, yaitu dosis iradiasi semakin tinggi menghasilkan pori semakin kecil. Hal ini mungkin disebabkan karena proses iradiasi menyebabkan terjadinya ikatan silang antara kitosan dan KMS, sehingga ukuran pori scaffold menjadi mengecil.
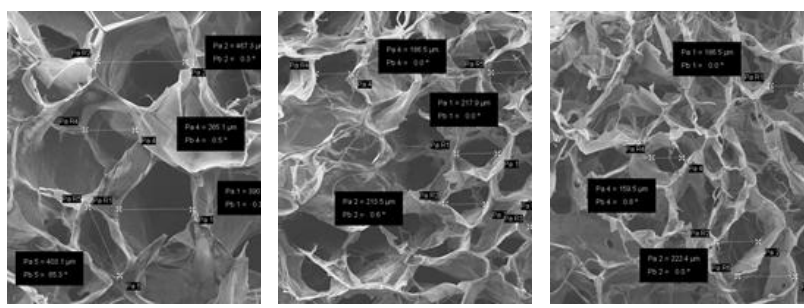

Gambar 2. Morfologi scaffold dengan SEM

Berdasarkan Karageorgiou dan Kaplan (2005) [10], persyaratan minimum ukuran pori scaffold adalah sekitar $100 \mu \mathrm{m}$. Persyaratan tersebut sesuai untuk kebutuhan migrasi dan trasportasi dari sel. Namun demikian, yang diharapkan dari scaffold tersebut bukan saja untuk kebutuhan sel, tetapi lebih jauh lagi yaitu pembentukan tulang baru dan kapiler. Untuk kebutuhan tersebut, diperlukan scaffold dengan besaran pori lebih dari $300 \mu \mathrm{m}$. Menurut Chen, et.al (2014) [11] pada pori-pori mikro, baik yang terdapat di dalam maupun di permukaan scaffold dapat mempercepat jebakan dan perlengketan sel. Pori-pori tersebut berfungsi sebagai kantong untuk memberi ruang bagi sel-sel untuk menyusup, menempel dan berkembang biak. Zhang et al. (2010) [12], telah pula mengamati diferensiasi osteogenik dari Bone Morphgenic Protein-7 (BMP-7), dimana diferensiasi osteogenik lebih baik terjadi pada pori berukuran antara 100-300 $\mu \mathrm{m}$ dibandingkan dengan 50-100 $\mu \mathrm{m}$ di dalam scaffold fibroin sutra. Han et al. (2015) [13] menambahkan pula bahwa ukuran pori scaffold fibroin sutra 90-250 $\mu \mathrm{m}$ memberi lingkungan terbaik untuk adhesi dan proliferasi kondrosit. Hal tersebut sejalan dengan hasil yang diperoleh pada penelitian ini yaitu ukuran pori sampel scaffold iradiasi $15 \mathrm{kGy}$ dan $25 \mathrm{kGy}$ berkisar antara $130-467 \mu \mathrm{m}$.

Parameter penting lainnya dari scaffold adalah kemampuannya untuk menyerap air. Pola penyerapan air scaffold KS-KMS dapat dilihat pada Gambar 3. Persen serapan air dari scaffold meningkat dengan bertambahnya waktu perendaman. Serapan maksimum dari scaffold KS-KMS terjadi setelah direndam dalam air selama 15 menit. Dosis iradiasi yang semakin tinggi memberi serapan air yang semakin rendah dari scaffold. Penyerapan air dari scaffold KSKMS berhubungan dengan besar porinya, dan besaran pori berhubungan dengan dosis iradiasi. Semakin besar pori scaffold, semakin besar serapan airnya. Pori dari scaffold kontrol lebih besar daripada scaffold iradiasi $15 \mathrm{kGy}$ dan scaffold iradiasi $15 \mathrm{kGy}$ lebih besar porinya dari pada scaffold iradiasi $25 \mathrm{kGy}$ dengan serapan air berturut-turut $1.722 \%, \quad 1.101 \%$, dan $803 \%$. Oksidasi radiasi pada polimer padatan dipengaruhi oleh dosis iradiasi. Hal ini akan mempengaruhi difusi oksigen ke dalam jejering polimer [14]. Oleh karenanya semakin kecil pori scaffold KSKMS semakin menurun kemampuan swelling akibat terjadinya degradasi oksidatif oleh radiasi.

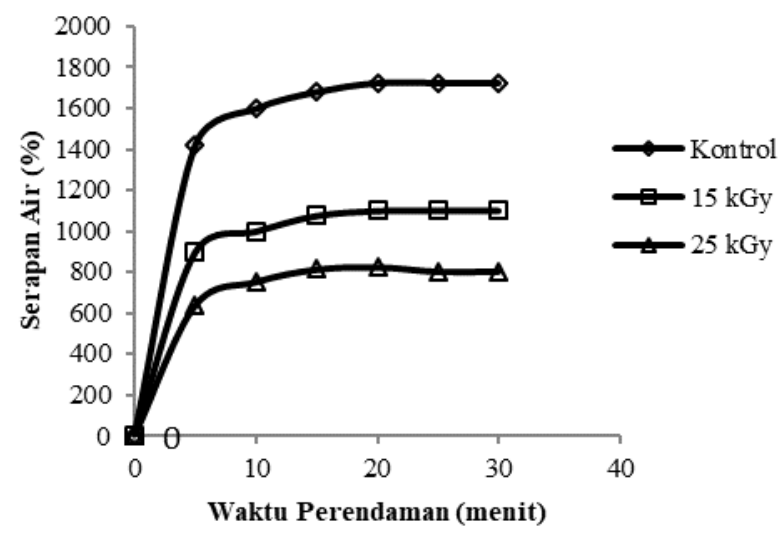

Gambar 3. Pola serapan air dari scaffold komposit KS-KMS

Persentase porositas scaffold KS-CMC non-iradiasi dan iradiasi dapat dilihat pada Gambar 4. Porositas scaffold non-iradiasi, iradiasi 15 dan $25 \mathrm{kGy}$, berturut-turut adalah $70,3 \%$, $72,7 \%$ dan $73,9 \%$. Scaffold dengan dosis iradiasi yang semakin tinggi diperoleh persen porositas yang tinggi pula. Hal ini dapat dimaklumi karena sesuai dengan definisi porositas yaitu rasio antara volume ruang kosong dengan volume massa dari material solid, maka semakin tinggi persen 
porositas dari suatu scaffold, semakin kecil ukuran porinya. Porositas dari scaffold juga behubungan dengan struktur 3D dari scaffold. Struktur 3D ini sangat berperan dalam memvasilitasi sel untuk bermigrasi ke dalam scaffold [15].

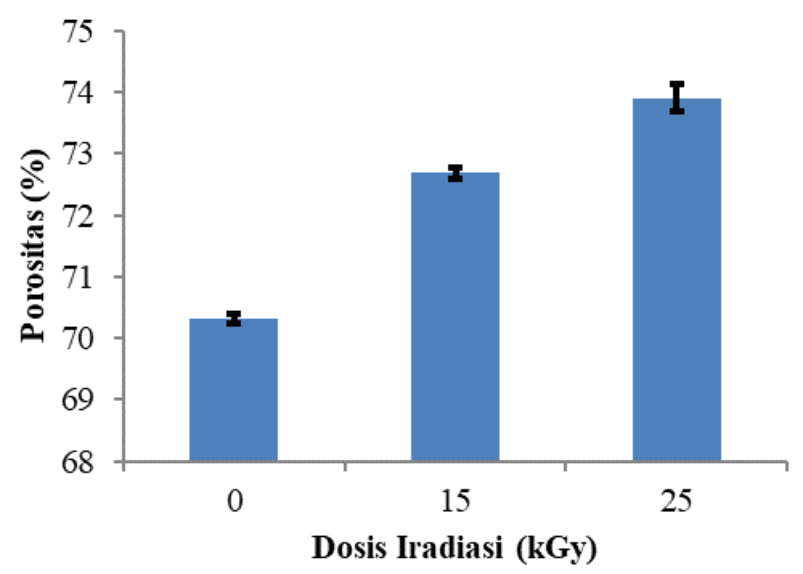

Gambar 4. Porositas Scaffold KS-KMS Non-Iradiasi dan Iradiasi.

Porositas dari scaffold KS-KMS ini telah memenuhi persyaratan dari porositas dasar untuk rekayasa jaringan yaitu sebesar 60\% [16]. Dengan demikian scaffold yang disiapkan dari KS-KMS ini mempunyai cukup ruang untuk meningkatkan proliferasi dan pertumbuhan sel.

\section{KESIMPULAN}

Dari hasil penelitian ini dapat disimpulkan bahwa komposit KS-KMS iradiasi memiliki ukuran pori berkisar 130-467 $\mu \mathrm{m}$ dan porositas berkisar antara 70,3\%, sampai $73,9 \%$ yang memenuhi persyaratan sebagai scaffold.

\section{UCAPAN TERIMA KASIH}

Ucapan terima kasih penulis sampaikan kepada Bapak Yasin dari Balai Iradiasi, Elektromekanik dan Instrumentasi PAIR-BATAN yang telah membantu dalam mengiradiasi sampel scaffold KS-KMS.

\section{DAFTAR PUSTAKA}

[1] Cai Q., Yang J., Wang S., A novel porous cells scaffold made of polylactide dextran blend by combining phaseseparation and particle-leaching techniques. Biomaterials, 23, 4483-4492, 2002.

[2] Ramakrishna S., Fujihara K., Teo W.E., Lim T.C., Ma Z., An introduction to electrospinning and nanofibers. World Scientific, 341-349, 2005.

[3] Chen Huangqin and Fan Mingwen, Chitosan/Carboxymethyl Cellulose Polyelectrolyte Complex Scaffolds for Pulp Cells Regeneration. Journal of Bioactive and Compatible Polymer, 22, 475-491, 2007.

[4] Llanos J.H.R., Vercik L.C.O., Vercik A., Physical properties of chitosan films obtained after neutralization of polycation by slow drip method, Journal of Biomaterials and Nanobiotechnology, 6, 276-291, 2015.

[5] Adel A.M., Abou-Youssef H, El-Gendy A.A., Nada A.M., Carboxymethylated cellulose hydrogel: Sorption behavior and characterization. Nature and Science, 8 (8), 244-256, 2010.

[6] Yusof N., Validation of radiation dose distribution in boxes for frozen and nonfrozen tissue grafts. In: Nather A.,Yusof N., and Hilmy $\mathrm{N}$ (eds) Radiation in Tissue Banking, World Sci, Singapore, pp. 187-199, 2007.

[7] Liu, C., Bai, R., Adsorptive Removal of Copper Ions with Highly Porous Chitosan/Cellulose Acetate Blend Hollow Fiber Membranes. Journal of Membrane Science. 284, 313-322, 2006.

[8] Heydarzadeh H.D., Najafpour G.D., NazariMoghaddam A.A., Catalyst-free conversion of alkali cellulose to fine carboxymethyl cellulose at Mild conditions. World Applied Sciences Journal, 6 (4), 564-569, 2009.

[9] Nwe N., Furuike T., Tamura H., The mechanical and biological properties of chitosan scaffolds for tissue regeneration 
templates are significantly enhanced by chitosan from gongronella butleri, Materials, 2, 374-398, 2009. doi: 10. 3390/ ma2020374.

[10] Karageorgiou, V., Kaplan D., Porosity of 3D biomaterial scaffolds and osteogenesis, Biomaterials, 26, 5474-5491, 2005.

[11] Chen C.H., Liu J.M.J., Chua C.K., Chou S.M., Shyu V.B.H., Chen J.P., Cartilage tissue engineering with silk fibroin scaffolds fabricated by indirect additive manufacturing technology, Materials, 7, 2104-2119, 2014. doi: 10.3390/ma7032104.

[12] Zhang Y., Fan W., Ma Z, Wu C., Fang W., Liu G., Xiao Y., The effects of pore architecture in silk fibroin scaffolds on the growth and differentia-tion of mesenchymal stem cells expressing BMP7. Acta Biomater. 6, 3021-3028, 2010. doi: $10.1016 /$ j.actbio. 2010.02.030.

[13] Han K.S., Song J.E., Tripathy N., Kim H., Moon B.M., Park C.H., Khang G.,
Effect of pore sizes of silk scaffolds for cartilage tissue engineering. Macromolecular Research.; 23, (12), 1091-1097, 2015. doi: 10.1007/ s13233015-3156-4.

[14] Desai K.G., Park H.J., Study of gammairradiation Effects on Chitosan Microparticles, Drug Delivery, 13, 3950, 2006.

[15] Amaral I.F., Sampaio P., Barbosa M.A., Three-dimensional culture of human osteoblastic cells in chitosan sponges: The effect of the degree of acetylation, Journal of Biomedical Materials Research Part A - February, 335-346, 2006. doi: $10.1002 / \mathrm{jbm}$.a. 30522.

[16] Zhang J., Yan D.X., Lei J., Xu J.Z., Hsiao B.S., Li Z.M., Ultraporous poly(lactic acid) scaffolds with improved mechanical performance using highpressure molding and salt leaching. $J$. Appl. Polym. Sci., 130, 3509-3520, 2013. 